\title{
Effect of competitive tactics on performance: The case of the pharmaceutical industry.
}

\author{
Completed Research Paper
}

\author{
Julen Castillo-Apraiz \\ Universidad del País Vasco/Euskal Herriko \\ Unibertsitatea UPV/EHU \\ julen.castillo@ehu.eus
}

\author{
Jesus Matey \\ Universidad del País Vasco/Euskal Herriko \\ Unibertsitatea UPV/EHU \\ jesus.matey@ehu.eus
}

\begin{abstract}
Competitive tactics play a key role in explaining different levels of organizational performance since they are the linkers between strategy formulation and implementation. This study focuses on two main competitive tactics, namely, Quality-Oriented Competitive Tactic (Quality) and Cost-Oriented Competitive Tactic (Cost), which are the ones that are closely related to Porter's generic competitive strategies. Apart from that, we will analyze two other important competitive tactics, namely, Innovation-Oriented Competitive Tactic (Innovation) and Marketing-Oriented Competitive Tactic (Marketing) which will mediate the relationship between the main tactics and performance. Hence, we try to adopt an integrative posture by viewing competitive tactics in the pharmaceutical industry as inextricably linked, forming the fundamental pillars on which sustainable competitive advantage could be established.
\end{abstract}

Keywords: Competitive tactics, Performance, Pharmaceutical industry.

\section{Introduction}

Prior research indicates that competitive tactics play a key role understanding an organization's sources of performance. They are linkers between strategy formulation and implementation; that is, they are necessary tools that help operationalize competitive strategy, forming the fundamental pillars on which sustainable competitive advantage can be established.

Several extant studies derive from the work of Dess and Davis (1984). These studies have focused on the relationships between each competitive tactic and performance, but there is a lack of a global model which includes not only the main competitive tactics but also the relationships between them. To help fill this gap, this paper contributes to the literature in analyzing the relationship between the competitive tactics that are closely related to Porter's generic competitive strategies (Porter, 1980, 1985, 1991), namely Quality-Oriented Competitive Tactic (Quality) and Cost-Oriented Competitive Tactic (Cost) and the two tactics that mediate the relationship between those tactics and performance, namely InnovationOriented Competitive Tactic (Innovation) and Marketing-Oriented Competitive Tactic (Marketing).

We contribute on this issue by focusing on the pharmaceutical industry, specifically on the German pharmaceutical industry, which is often the source of benchmarking data due to its high level of profitability. 
Managers and researchers should adopt a more integrative posture by viewing competitive tactics as inextricably linked, forming the fundamental pillars on which sustainable competitive advantage could be established. It is important to know the impact of each competitive tactic on performance since managers are often facing resource shortages and they need to focus on what leads on a higher performance.

\section{Literature review and conceptual model}

\subsection{Competitive tactics}

Competitive tactics are tools that help us translate into more concrete actions a strategy that is already formulated. They help firms implement their strategies (Barney, 2002). Thus, competitive tactics reflect the strategic orientation of the firm (Akan, Allen, Helms, \& Spralls, 2006).

There is a lack of consensus about the concept of competitive tactics. In fact, some authors who have label this concept differently. For instance, Bourgeois (1980) talks about competitive weapons, while Allen and Helms (2006) talk about specific strategic practices. Other studies (e.g., Ferrier, Fhionnlaoich, Smith, \& Grimm, 2002; Fernández \& Usero, 2009; Otero \& Varela, 2008) analyze competitive actions. Green, Lisboa and Yasin (1993) use the concept of competitive methods used previously by Dess and Davis (1984). Dess and Davis (1984) argue that "these competitive methods provide a means for characterizing the strategies of competitors within an industry" (p. 470).

Competitive tactics, whatever definition is used, are linked to the performance of firms, which is the dependent variable in our study. It is important to consider performance in a broad sense in order to capture a great part of its meaning (see Section 3.2).

The competitive tactics that will be analyzed, which are based on Dess and Davis (1984) and Robinson and Pearce (1988), are Quality, Cost, Innovation and Marketing. The major features of each competitive tactic applied to the pharmaceutical industry are described below.

The two main tactics, which are closely related to Porter's generic competitive strategies, are Quality and Cost (not mutually exclusive). Quality involves acquiring a high level of reputation in the industry, investing in process research, development and innovation (R\&D\&I), having strict quality control procedures and extensive customer service. Quality is an important tactic mainly for pioneers, which are firms that are more focused on quality; by definition, pioneer firms try to be first-to-market. Cost involves making a great effort for reducing costs, trying to have lower prices than the ones of the competitors, focusing on low price marked segments etc. This tactic would be more effective in the case of followers, which are firms that wait until the loss of patent protection of the drugs that were developed by pioneers.

The other two competitive tactics are Innovation and Marketing. They also play an important role in the model since they mediate the relationships between the main tactics and performance. Innovation consists of developing new drugs and developing and refining the existing ones, focusing in specialized products and in high-priced segments. Marketing consists of trying to gain strong brand identification, focusing on promoting and advertising and on its quality and trying to innovate in marketing techniques.

Firstly, Innovation mediates the relationship between Cost and performance (mediation 1). Zahra and Covin (1993) conclude that cost orientation is positively related to innovation orientation, whereas surprisingly Radas (2005) does not conclude that firms focusing on a cost orientation innovate less than the ones that follow mainly a quality orientation. Hilman and Kaliappen (2014) do demonstrate that Innovation partially mediates the relationship 
between Cost and performance, with a positive relationship between the variables. Nevertheless, we argue that firms focusing on a cost orientation would not be the ones that would take advantage of a bigger orientation to innovation (Robinson \& Pearce, 1988; Zahra, 1993). In other words, we defend that Cost would have a negative impact on Innovation, since an emphasis on a cost reduction would make it difficult to discover new drugs or develop the existing ones.

Secondly, Marketing mediates the relationship between Quality and performance (mediation 2). Some works defend that Marketing and Quality are interrelated, highlighting the impact of Marketing on performance (e.g., Lai, 2003; Lai \& Cheng, 2005; Lai, Yeung, \& Cheng, 2012). Du and Wan (2008) defend that an emphasis on Quality needs the mediation of Marketing in order to have a significant impact on performance, whereas Homburg, Krohmer and Workman (2004) conclude that this mediation is partial.

Thirdly, we propose that Marketing mediates the relationship between Innovation and performance (mediation 3). Both followers and pioneers need to make the customers see the benefits of their products but it is more important in the case of pioneers since their drugs add incremental benefits to the ones that are already been commercialized. Pioneers are said to be the ones benefitting more from an innovation orientation, and as proposed by Geroski and Murfin (1990), when benefits of Marketing are to be sustainable in the long term, an aggressive technological posture is appropriate. This posture is usually closely linked to the innovation level.

The research hypotheses to be tested are:

Hypotheses 1-4: Quality-Oriented Competitive Tactic (1), Cost-Oriented Competitive Tactic (2), Innovation-Oriented Competitive Tactic (3) and Marketing-Oriented Competitive Tactic (4) have a positive impact on performance.

Hypothesis 5: The direct relationship between Cost-Oriented Competitive Tactic and performance is mediated by Innovation-Oriented Competitive Tactic.

Hypothesis 6: The direct relationship between Quality-Oriented Competitive Tactic and performance is mediated by Marketing-Oriented Competitive Tactic.

Hypothesis 7: The direct relationship between Innovation-Oriented Competitive Tactic and performance is mediated by Marketing-Oriented Competitive Tactic.

\section{Research methodology}

\subsection{Sample and data collection}

Our population comprises all the German pharmaceutical firms operating under the 2834 SIC code, based on Dun \& Bradstreet Database (928 firms). We chose German pharmaceutical firms as the sample for this study because this German industry is a clear source of benchmarking data, that is, the results obtained using the data from the German pharmaceutical industry could be extended to many other countries. Using the computerassisted telephone interviewing (CATI) procedure and conducting stratified proportional sampling that covered the original population, 200 valid responses were obtained from CEOs in the German pharmaceutical industry with the help of a German institute. The sample represents around $21.6 \%$ of the population. The sample was stratified (stratified proportional sampling) by firm size (measured by the total number of employees), federal state, and turnover. In order to obtain 200 valid responses, 597 managers were interviewed; thus, the final response rate was around $33.5 \%$. For every firm in the sample, we collected data associated with the 3-year period immediately before and after the enactment of the Act on 
the Reform of the Market for Medicinal Products (AMNOG) in 2011, trying to avoid the effect of the law on the relationships. The data were collected in mid-2014.

The Ten Times Rule is a rule of thumb which gives the researcher an approximation of the required sample size. We took into account the largest number of predictors for a particular dependent variable, in this case 4 (Chin, 2010). Then, the minimum would be $4.10=40$. Nevertheless, a power analysis must be conducted in order to ensure accuracy, given that sample size is extremely dependent on the particular SEM model (Chin, 1998). Taking the work of Cohen (1992, Table 1) as a reference point and keeping in mind that we are testing a multiple regression model, the effect size value is 0.15 , if we consider the average effect of observed effects is to be medium. Since the level of significance is $5 \%$, a minimum of 84 observations would be needed, following Cohen (1992, Table 2). That is, over than 84 observations would be needed if the investigator wants to verify the statements with a power of $80 \%$. We conducted an additional power analysis using the G*Power software following Faul, Erdfelder, Lang and Buchner (2007), and we reached the same conclusion as that in the first power analysis.

Thus, with a sample size of 400 , we exceeded the threshold required. Therefore, we can conclude that our sample was representative of the population. Although the sample size is big, it does not pose a problem due to the partial nature of the partial least squares PLS regression technique (Chin, 2010).

\subsection{Measures}

Following Diamantopoulos, Sarstedt, Fuchs, Sebastian and Wilczynski (2012), the dependent and independent variables were measured using the means of multiple items on 5point Likert scales, ranking from 1 ("much below the average") to 5 ("much above the average"). Consistent with prior research, we adapted the existing measurement scales for the competitive tactics that were validated in the extant literature (e.g., Dess \& Davis, 1984; Robinson \& Pearce, 1988; Ruiz-Ortega \& García-Villaverde, 2008) thereby ensuring high reliability of our results.

The measurement scale for performance was based on Akan et al. (2006) and Allen and Helms (2006). On the one hand, most researchers agree that multiple measures offer a rich perspective that cannot be provided by a single approach. On the other hand, respondents may be reluctant to give the figures. We take into account the increase in the number of employees following the publication of prior studies (e.g., Davis \& Pett, 2002; Durand \& Coeurderoy, 2001; Lee, Koo, \& Nam, 2010).

\subsection{Results of data analysis}

The data analysis was performed using the partial least squares structural equation modeling (PLS-SEM) technique, which is a useful multivariate method in strategic management (Hair, Sarstedt, Pieper, \& Ringle, 2012). We used the SmartPLS 3 Professional (Ringle, Wende, \& Becker, 2014) software. Figure 1 shows the final structural model (Model 4). All the constructs are defined in a reflective way since the causality goes from the variable to the items (Podsakoff, Shen, \& Podsakoff, 2006). 


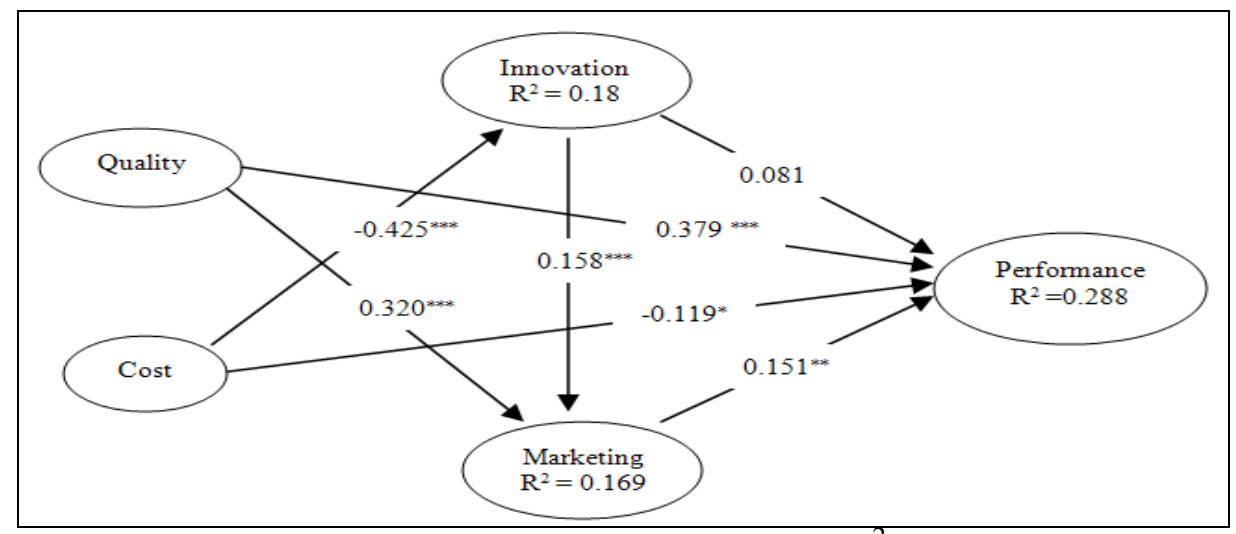

Figure 1: Structural model (Model 4): Path coefficients and $\mathrm{R}^{2}$

Note: Lohmöller settings were used. The pairwise deletion algorithm was used to handle missing data. $* * * \mathrm{p}<.01 ; * * \mathrm{p}<.05 ; * \mathrm{p}<.1$

Following Klarner, Sarstedt, Hoeck and Ringle (2013), we engaged in a step-by-step analysis of the structural model. Model 1 is composed of the two main tactics, namely, Quality and Cost, and performance. Model 2 is composed of the main tactics and mediation 1, Model 3 of the main tactic and mediation 2 and Model 4 of the main tactics and mediation 1, mediation 2 and mediation 3, simultaneously (Figure 2).

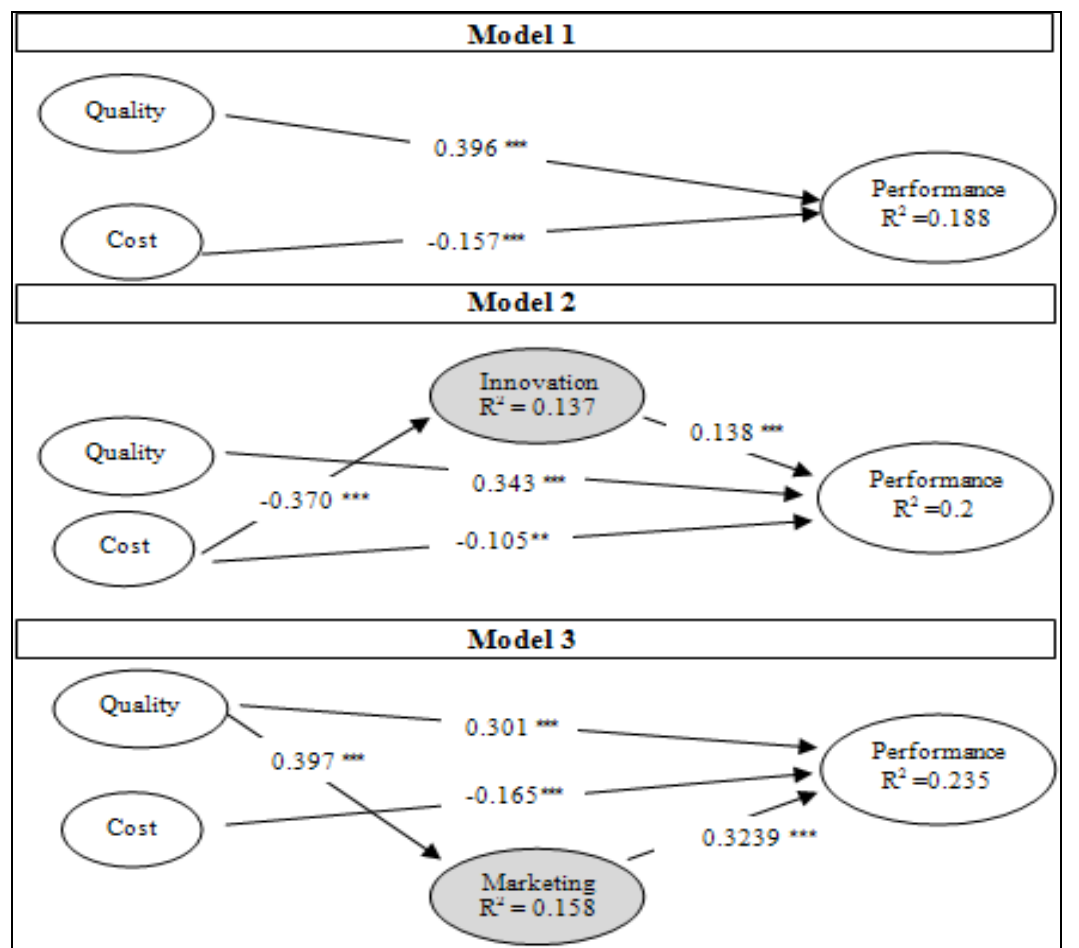

Figure 2: Structural model with separate analysis of mediators: Path coefficients and $\mathrm{R}^{2}$ $* * * \mathrm{p}<.01 ; * * \mathrm{p}<.05 ; * \mathrm{p}<.1$

Before analysing Model 4, both measurement model and structural model assessments were conducted firstly for Model 1, Model 2 and Model 3. Some of the results of the measurement models' assessments are shown in Table 1. The smallest factor loadings in those models are 0.692, 0.692 and 0.695, respectively. Both composite reliability (CR) and average variance extracted (AVE) meet common thresholds of 0.7 for CR (Nunally \& Bernstein, 1994) and 0.5 for AVE (Fornell \& Larcker, 1981). Cronbach's alpha is considered as a conservative measure of internal consistency reliability. Cronbach's $\alpha$ values are above or 
very close to 0.7 (Nunally \& Bernstein, 1994). We assessed the discriminant validity using the heterotrait-monotrait ratio of correlations (HTMT), following Henseler, Ringle and Sarstedt (2014). In all cases values are below the threshold of $85 \%$ (Kline, 2011). Following Henseler et al. (2014), we report the standardized root mean square residual (SRMR), which are respectively $0.049,0.095$ and 0.039 , that is, fair fit or close, following Browne and Cudeck (1993).

Table 1: Evaluation results: Measurement model-Model 1, Model 2 and Model 3

\begin{tabular}{lccc|ccc|ccc}
\hline & \multicolumn{3}{c}{ Model 1 } & \multicolumn{3}{c}{ Model 2 } \\
\hline $\begin{array}{l}\text { Constructs/ } \\
\text { indicators }\end{array}$ & CR & $\begin{array}{c}\text { Cronbach's } \\
\alpha\end{array}$ & AVE & CR & $\begin{array}{c}\text { Cronbach's } \\
\alpha\end{array}$ & AVE & CR & $\begin{array}{c}\text { Cronbach's } \\
\alpha\end{array}$ & AVE \\
\hline Quality & 0.808 & 0.683 & 0.512 & 0.808 & 0.683 & 0.512 & 0.808 & 0.683 & 0.512 \\
Cost & 0.886 & 0.810 & 0.722 & 0.887 & 0.810 & 0.724 & 0.886 & 0.810 & 0.722 \\
Innovation & & & & 0.804 & 0.698 & 0.507 & & & \\
Marketing & & & & & & & 0.926 & 0.891 & 0.761 \\
Performance & 0.949 & 0.935 & 0.757 & 0.949 & 0.935 & 0.757 & 0.949 & 0.935 & 0.757 \\
\hline
\end{tabular}

Note: $\mathrm{CR}=$ Composite reliability; $\mathrm{AVE}=$ Average variance extracted.

The Structural model assessment of Model 1, Model 2 and Model 3 is shown in Table 2. The target constructs' percentage of variance explained $\left(\mathrm{R}^{2}\right)$ is a key criterion. The explanatory level of the models is around $20 \%$. The Stone-Geisser criterion $\mathrm{Q}^{2}$ values are obtained from running blindfolding procedures and range above the threshold level of zero, indicating that the exogenous constructs have predictive relevance for the endogenous construct under consideration. There are no collinearity problems since each construct's tolerance measured by the variance inflation factor (VIF) is higher than 0.2 and lower than 5 . Boostrapping has been used to assess the significance of path coefficients.

Table 2: Assessment of structural model-Model 1, Model 2 and Model 3

\begin{tabular}{lcc|cc|cc}
\hline & \multicolumn{2}{c}{ Model 1 } & \multicolumn{2}{c}{ Model 2 } & \multicolumn{2}{c}{ Model 3 } \\
\hline $\begin{array}{l}\text { Endogenous } \\
\text { constructs }\end{array}$ & $\mathrm{R}^{2}$ & $\mathrm{Q}^{2}$ & $\mathrm{R}^{2}$ & $\mathrm{Q}^{2}$ & $\mathrm{R}^{2}$ & $\mathrm{Q}^{2}$ \\
\hline $\begin{array}{l}\text { Innovation } \\
\text { Marketing }\end{array}$ & & & $13.7 \%$ & 0.047 & & 0.117 \\
Performance & $18.8 \%$ & 0.14 & $20 \%$ & 0.149 & $23.5 \%$ & 0.176
\end{tabular}

\begin{tabular}{|c|c|c|c|c|c|c|c|c|c|}
\hline Path & $\begin{array}{l}\text { Path } \\
\text { coeff. }\end{array}$ & VIF & $t$-value & $\begin{array}{l}\text { Path } \\
\text { coeff. }\end{array}$ & VIF & $t$-value & $\begin{array}{l}\text { Path } \\
\text { coeff. }\end{array}$ & VIF & $t$-value \\
\hline $\begin{array}{l}\text { Quality } \rightarrow \\
\text { Performance }\end{array}$ & 0.396 & 1.003 & $\begin{array}{c}10.105 \\
* * *\end{array}$ & 0.343 & 1.207 & $\begin{array}{c}7.230 \\
* * *\end{array}$ & 0.301 & 1.191 & $\begin{array}{c}6.594 \\
* * *\end{array}$ \\
\hline $\begin{array}{l}\text { Cost } \rightarrow \\
\text { Performance }\end{array}$ & -0.157 & 1.003 & $\begin{array}{c}3.579 \\
* * *\end{array}$ & -0.105 & 1.173 & $\begin{array}{c}2.089 \\
* * *\end{array}$ & -0.165 & 1.004 & $\begin{array}{c}4.009 \\
* * *\end{array}$ \\
\hline $\begin{array}{l}\text { Cost } \rightarrow \\
\text { Innovation }\end{array}$ & & & & -0.370 & 1.000 & $\begin{array}{c}8.201 \\
* * *\end{array}$ & & & \\
\hline $\begin{array}{l}\text { Quality } \rightarrow \\
\text { Marketing }\end{array}$ & & & & & & & 0.397 & 1.000 & $\begin{array}{c}8.679 \\
* * *\end{array}$ \\
\hline $\begin{array}{l}\text { Innovation } \rightarrow \\
\text { Marketing }\end{array}$ & & & & & & & & & \\
\hline $\begin{array}{l}\text { Innovation } \rightarrow \\
\text { Performance }\end{array}$ & & & & 0.138 & 1.394 & $\begin{array}{c}2.779 \\
* * *\end{array}$ & & & \\
\hline $\begin{array}{l}\text { Marketing } \rightarrow \\
\text { Performance }\end{array}$ & & & & & & & 0.239 & 1.189 & $\begin{array}{c}5.106 \\
* * *\end{array}$ \\
\hline
\end{tabular}

Note: Path coeff. $=$ Path coefficient. The cross-validated redundancy measure $\mathrm{Q}^{2}$ is derived from the blindfolding procedure with an omission distance of 7 . The $t$ - values are derived from the bootstrapping procedure with 400 cases, 5,000 samples, and the pairwise deletion algorithm. VIF $=$ variance inflation factor.

$* * * \mathrm{p}<.01 ; * * \mathrm{p}<.05 ; * \mathrm{p}<.1$ 
Assessing mediation 1 (model 2), mediation 2 (model 3) and mediation 3 (model 4), we need to compare each model with model 1 , model 1 and model 2 , respectively.

In order to assess the mediation 1, we checked first if Cost $\rightarrow$ Performance path is statistically significant in model 1 ( $t$ value of 3.579, $\mathrm{p}<0.01)$. Then, we checked that both indirect effects were significant in Model 2 (Cost $\rightarrow$ Innovation path's $t$ value $=8.201, \mathrm{p}<$ 0.01 ; Innovation $\rightarrow$ Performance path's $t$ value $=2.779, \mathrm{p}<0.01)$. Considering the sample mean in boostrappings, the direct effect decreased (in model 1 it was 0.163 whereas in model 2 it is 0.106). Following Preacher and Hayes (2004; 2008), we calculated the standard deviation (0.018) of the indirect effect of all the 5000 subsamples. Dividing the original value of the path coefficient obtained in the bootstrapping $(0.105)$ by the standar deviation $(0.018)$ we obtained the $t$ value of the indirect effect $(5.83, \mathrm{p}<0.01)$, which was significant. The variance accounted for (VAF) was 33\%, that is, there is a partial mediation (Table 3 ).

Similarly, we assessed mediation 2 and mediation 3. Since VAF was in both cases larger than $20 \%$ (24\% and 34\%, respectively), both are also partial mediations (Table 3 ).

Table 3: Separate analysis of mediating effects

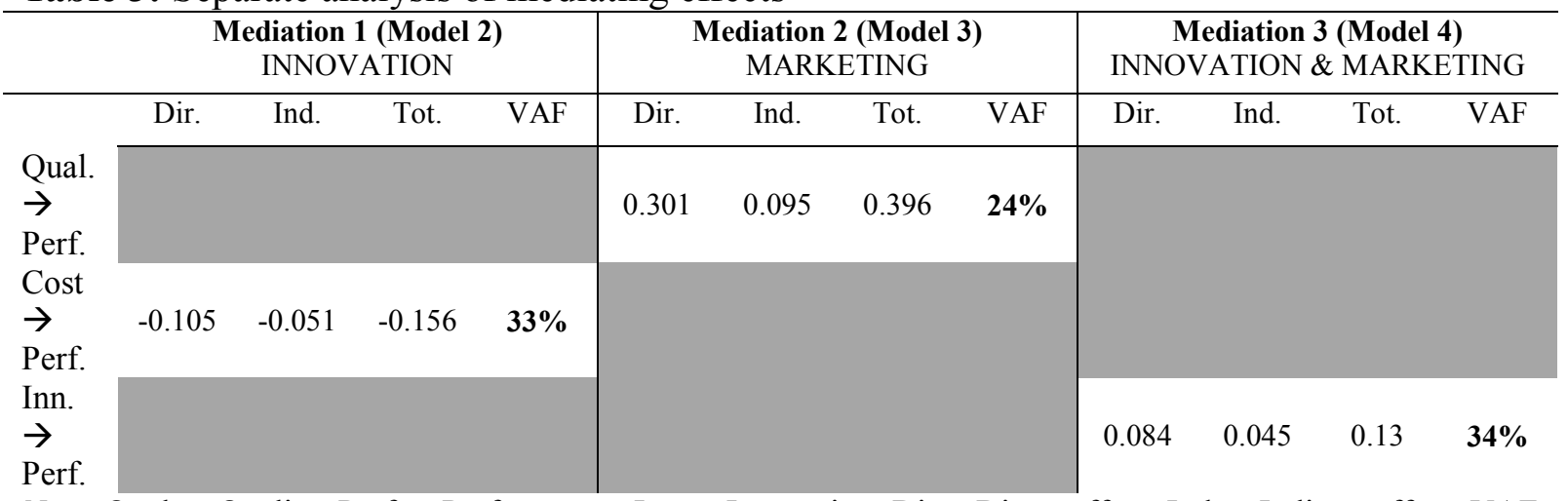

Note: Qual. $=$ Quality; Perf. $=$ Performance; Inn. $=$ Innovation; Dir $=$ Direct effect; Ind. $=$ Indirect effect; VAF= Variance accounted for.

The results of the final model (Model 4) are shown in Figure 1. Table 4 and Table 5 present the assessment of the measurement model. Assessing the internal consistency reliability, all the CR values were above 0.7 . Cronbach's $\alpha$ values are above or very close to 0.7. Convergent validity was assessed using AVE values. All the values were above or very close to 0.5 . We assessed discriminant validity using HTMT. In all cases, the values were below the threshold of $85 \%$ (Kline, 2011). The SRMR is 0.07 (a fair fit following Browne and Cudeck, 1993). Table 6 shows the assessment of the structural model.

Table 4: Evaluation results. Measurement model-Model 4

\begin{tabular}{|c|c|c|c|c|}
\hline Constructs/indicators & Loading & Composite reliability & Cronbach's $\alpha$ & AVE \\
\hline Quality-orientated Competitive Tactic & & 0.797 & 0.663 & 0.497 \\
\hline - Extensive customer service (Q_custom) & 0.713 & & & \\
\hline - Process oriented R\&D\&I (Q_proIDi) & 0.712 & & & \\
\hline - Strict quality control (Q_qu_contr) & 0.633 & & & \\
\hline - Reputation in industry (Q_repu) & 0.756 & & & \\
\hline Cost-orientated Competitive Tactic & & 0.890 & 0.8816 & 0.731 \\
\hline - Low-priced market segment (C_low_p_s) & 0.871 & & & \\
\hline - Lowest cost per unit $\left(\mathrm{C}_{-}\right.$lowcost $\left.\bar{c}\right)$ & 0.781 & & & \\
\hline - Pricing below competitors (C_price_b) & 0.908 & & & \\
\hline Innovation-Oriented Competitive Tactic & & 0.799 & 0.678 & 0.498 \\
\hline - New product development (I_NPD) & 0.722 & & & \\
\hline - High-priced market segments (I_highPseg) & 0.690 & & & \\
\hline - Specialised products (I_special_pt) & 0.733 & & & \\
\hline - Develop and refine established products & 0.676 & & & \\
\hline
\end{tabular}


(I_stablish)

Marketing-Orientated Competitive Tactic

0.918

0.879

0.738

- Influence in distribution channels (M_distr)

- Innovation in marketing techniques

(M_mk_tech)

- Promote and advertise above industry

(M_promo)

- Efforts in quality of advertising (M_q_adv)

0.921

Performance

0.738

0.943

0.927

0.736

- Growth in number of employees

0.738

(P EMPLOYEE)

- Total asset growth (P_asset) 0.897

- Net income growth ( $\mathrm{P}_{-}$income $)$

- Overall performance / success (P_overall) 0.903

- Total revenue growth (P_revenue) 0.858

- Market share growth ( $\mathrm{P} \_$share $) \quad 0.893$

Note. $\mathrm{AVE}=$ Average variance extracted.

Table 5: Discriminant validity assessment: Heterotrait-monotrait ratio of correlations-Model 4

\begin{tabular}{lccccc} 
& Cost & Innovation & Marketing & Performance & Quality \\
\hline Cost & & & & & \\
Innovation & -0.491 & & & & \\
Marketing & -0.033 & 0.374 & & & \\
Performance & -0.255 & 0.421 & 0.353 & & \\
Quality & -0.225 & 0.639 & 0.49 & 0.619 & \\
\hline
\end{tabular}

Table 6: Assessment of structural model: Model 4

\begin{tabular}{|c|c|c|c|c|c|c|}
\hline $\begin{array}{l}\text { Endogenous } \\
\text { constructs }\end{array}$ & \multicolumn{3}{|c|}{$\mathrm{R}^{2}$} & \multicolumn{3}{|c|}{$\mathrm{Q}^{2}$} \\
\hline Innovation & \multicolumn{3}{|c|}{0.18} & \multicolumn{3}{|c|}{0.067} \\
\hline Marketing & \multirow{2}{*}{\multicolumn{3}{|c|}{0.169}} & \multicolumn{3}{|c|}{0.111} \\
\hline Performance & & 0.288 & & \multicolumn{3}{|c|}{0.208} \\
\hline Path & $\begin{array}{l}\text { Path } \\
\text { coefficient }\end{array}$ & $\begin{array}{l}\text { Collinearity } \\
\text { (VIF) }\end{array}$ & $\mathrm{f}^{2}$ & $t$-value & $\begin{array}{l}\text { Bias corrected } \\
95 \% \text { CI } \\
\text { (direct effects) }\end{array}$ & $\begin{array}{l}\text { Bias corrected } \\
95 \% \text { CI } \\
\text { (indirect effects) }\end{array}$ \\
\hline Quality $\rightarrow$ Performance & 0.379 & 1.325 & 0.072 & $5.560 * * *$ & {$[0.250 ; 0.513]$} & {$[0.006 ; 0.098]$} \\
\hline Cost $\rightarrow$ Performance & -0.119 & 1.236 & 0.021 & $1.820^{*}$ & {$[-0.258 ;-0.012]$} & {$[-0.109 ; 0.013]$} \\
\hline Cost $\rightarrow$ Innovation & -0.425 & 1.000 & 0.115 & $6.768 * * *$ & {$[-0.559 ;-0.326]$} & \\
\hline Quality $\rightarrow$ Marketing & 0.320 & 1.199 & 0.096 & $4.934 * * *$ & {$[0.205 ; 0.458]$} & \\
\hline Innovation $\rightarrow$ Marketing & 0.158 & 1.199 & 0.042 & $2.480 * *$ & {$[0.050 ; 0.299]$} & \\
\hline Innovation $\rightarrow$ Performance & 0.081 & 1.470 & 0.006 & 1.338 & {$[0.005 ; 0.239]$} & {$[0.001 ; 0.061]$} \\
\hline Marketing $\rightarrow$ Performance & 0.151 & 1.219 & 0.051 & $2.401 * *$ & {$[0.025 ; 0.274]$} & \\
\hline Cost $\rightarrow$ Marketing & & & & & & {$[-0.122 ;-0.017]$} \\
\hline $\begin{array}{l}\text { Note: The cross-validated } \\
\text { distance of } 7 \text {. The effect } \\
\text { variable. The } t \text { - values ar } \\
\text { pairwise deletion algorith } \\
* * * \mathrm{p}<.01 ; * * \mathrm{p}<.05 ; *\end{array}$ & $\begin{array}{l}\text { indancy } \\
\left(f^{2}\right) \text { all } \\
\text { rived } f \mathrm{f} \\
\mathrm{IF}=\mathrm{va} \\
1\end{array}$ & $\begin{array}{l}\text { ure }\left(Q^{2}\right) \\
\text { ie asses } \\
\text { te boots }\end{array}$ & erive & $\begin{array}{l}\text { n the bli } \\
\text { struct's } \\
\text { dure wit }\end{array}$ & $\begin{array}{l}\text { lding procedure } \\
\text { tribution to an e } \\
00 \text { cases, } 5,000\end{array}$ & $\begin{array}{l}\text { ith an omission } \\
\text { dogenous latent } \\
\text { amples, and the }\end{array}$ \\
\hline
\end{tabular}

\section{Results and conclusion}

This study attempts to shed some light on the important issue of competitive tactics since they play a key role in understanding the sources of performance of organizations.

Managers and researchers should adopt a more integrative posture by viewing competitive tactics as inextricably linked, forming the fundamental pillars on which sustainable competitive advantage could be established. We seek to fill a gap in the business literature by 
developing an integrative framework that outlines the relationships between the main competitive tactics.

We conducted a step-by-step analysis to test the hypotheses. For the main competitive tactics, our findings reveal that Quality (Table 6; path coefficient of $0.379, \mathrm{p}<0.01$ ) has a positive influence on performance, confirming Hypothesis 1. Surprisingly, Cost has a negative effect on performance (Table 6; path coefficient of $-0.119, \mathrm{p}<0.1$ ), not supporting Hypothesis 2. Following Dess, Lumpkin and Covin (1997), “(...) since the cost leadership scale assesses this strategic attribute rather than the change in this attribute, the negative correlation with profitability is not counterintuitive as it may initially appear" (p. 688).

Confirming Hypothesis 5, the direct relationship between Cost and performance is mediated by Innovation. Likewise, Hypothesis 6 is supported, that is, the direct relationship between Quality and performance is mediated by Marketing.

Marketing has a significant impact on performance (Table 6; path coefficient of $0.151, p$ $<0.05$ ), confirming Hypothesis 4.

In Model 2, that is, before including Marketing in the analysis, Innovation had a significant effect on performance (Table 2; path coefficient of $0.138, p<0.01$ ). Nevertheless, when both Innovation and Marketing (Model 4) were included, the significant mediating effect of Marketing between Innovation and performance (Hypothesis 7) caused the rejection of Hypothesis 3, that is, Innovation has not a significant effect on performance (Table 6; path coefficient of $0.081, \mathrm{p}>0.1$ ).

Considering the effect size $\left(\mathrm{f}^{2}\right)$ values (Table 6), researchers and managers should also take into consideration that, with the exception of the effect of Cost on performance, the largest contribution of a construct towards explaining the variance of performance is Quality. Hence, in the pharmaceutical industry managers really need to focus on quality.

\section{Limitations and directions for further research}

As with any empirical research, our study is not without limitations. Firstly, only the main competitive tactics were included as predictors of performance in this study. Other constructs (such as capabilities) could have been included for a better explanation of performance. Further, we have analyzed restricted aspects of performance only. Secondly, the managers were not asked for objective measures since "German managers, for example, emphasize privacy of information to a greater extent than managers in other cultures" (Homburg et al., 2004 , p. 1336). We think that respondents would have been reluctant to give the figures. The relative comparisons of the managers' responses might be problematic due to the subjectivity of perceptions. However, following Spanos and Lioukas (2001), we think that managers' perceptions properly reflect the strategic behavior of their firms. Thirdly, since we studied German pharmaceutical firms, it must be acknowledged that the path coefficients could differ significantly across countries and sectors, that is, the results should be extrapolated with extreme caution.

The effect of competitive tactics on performance differs depending on the moment of entry of the business, that is, entry timing is considered a key factor that warrants attention. Researchers can go a step further considering the moment of entry as a discrete variable and using, for example, the theoretical Golder and Tellis's (1993) definition of market pioneering, that is, market pioneers are the first businesses who sell their products in a concrete product category. The sample could be divided into two (Pioneers vs. Followers) like some authors suggested (e.g., Covin, Slevin, \& Heeley, 1999; Kerin, Varadarajan, \& Peterson, 1992; Shamsie, Phelps, \& Kuperman, 2004) or even into three groups (Pioneers vs. Early Followers vs. Late Followers) following other works (e.g., De Castro \& Chrisman, 1995; Durand \& 
Coeurderoy, 2001; Ruiz-Ortega \& García-Villaverde, 2008). Then, the path coefficients for every group could be analyzed. Conducting a multigroup analysis it could be assessed whether differences in the path coefficients are statistically significant.

\section{Acknowledgments}

We would like to thank Dr. Joaquín Aldás Manzano (Universitat de València University, Spain) and Dr. Christian M. Ringle (Technische Universität Hamburg-Harburg University, Germany) for their helpful comments and insights. Any remaining errors or omissions are the authors' alone. We highly appreciate the financial support received from the Fundación Emilio Soldevilla para la Investigación y el Desarrollo en Economía de la Empresa (FESIDE) foundation and the Unidad de Formación e Investigación en Dirección Empresarial y Gobernanza Territorial y Social (UFI 11/51) research and training unit. We also thank the anonymous reviewers for their feed-back.

\section{References}

Akan, O., Allen, R. S., Helms, M. M., \& Spralls, S. A., III (2006). Critical tactics for implementing Porter's generic strategies. Journal of Business Strategy, 27(1), 43-53.

Allen, R. S., \& Helms, M.M. (2006). Linking strategic practices and organizational performance to Porter's generic strategies. Business Process Management Journal, $12(4), 433-454$.

Barney, J. B. (2002): Gaining and sustaining competitive advantage. New Jersey: Prentice Hall.

Bourgeois, L. J. (1980). Performance and consensus. Strategic Management Journal, 1(3), 227-248.

Browne, M. W., \& Cudeck, R. (1993). Alternative ways of assessing model fit. In K.A. Bollen, \& J. S. Long (Eds), Testing Structural Equation Models (pp. 136-162). California: Sage.

Chin, W. W. (1998). Commentary: Issues and opinion on Structural Equation Modeling. MIS Quarterly, 22(1), 7-16.

Chin, W. W. (2010). How to write up and report PLS analyses. In V. Esposito, W. W. Chin, J. Henseler \& H. Wang (Eds.). Handbook of partial least squares: Concepts, methods and applications (pp. 655-690). Berlin: Springer-Verlag.

Cohen, J. (1992). A power primer. Psychological Bulletin, 112(1), 155-159.

Covin, J. G., Slevin, D.P., \& Heeley, M.B. (1999). Pioneers and Followers: Competitive tactics, environment, and firm growth. Journal of Business Venturing, 15(2), 175-210.

Davis, P. S., \& Pett, T. L. (2002). Measuring organizational efficiency and effectiveness. Journal of Management Research, 2(2), 87-97.

De Castro, J. O., \& Chrisman, J. J. (1995). Order of market entry, competitive strategy, and financial performance. Journal of Business Research, 33(2), 165-177.

Dess, G. G., \& Davis, P. S. (1984). Porter's (1980) generic strategies as determinants of strategic group membership and organizational performance. Academy of Management Journal, 27(3), 467-488.

Dess, G. G., Lumpkin, G. T., \& Covin, J. G. (1997). Entrepreneurial strategy making and firm performance: Tests of contingency and configurational models. Strategic Management Journal, 18(9), 677-695. 
Diamantopoulos, A., Sarstedt, M., Fuchs, C., \& Wilczynski, P., \& Sebastian, K. (2012). Guidelines for choosing between multi-item and single-item scales for construct measurement: a predictive validity perspective. Journal of the Academy of Marketing Science, 40(3), 434-449.

Du, P., \& Wan, H. (2008). An empirical study on the relationship of market orientation, quality orientation and business performance. Journal of Chinese Marketing, 1, 1-8.

Durand, R., \& Coeurderoy, R. (2001). Age, order of entry, strategic orientation and organizational performance. Journal of Business Venturing, 16(5), 471-494.

Faul, F., Erdfelder, E., Lang, A. G., \& Buchner, A. (2007). G*Power 3: A flexible statistical power analysis program for the social, behavioral, and biomedical sciences. Behavior Research Methods, 39(2), 175-191.

Fernández, Z., \& Usero, B. (2009). Competitive behavior in the European mobile telecommunications industry: Pioneers vs. Followers. Telecommunications Policy, 33(7), 339-347.

Ferrier, W. J., Fhionnlaoich, C. M., Smith, K. G., \& Grimm, C. M. (2002). The impact of performace distress on agressive competitive behavior: a reconciliation of conflicting views. Managerial and Decisions Economics, 23(4-5), 301-316.

Fornell, C., \& Larcker, D. F. (1981). Structural equation models with unobservable variables and measurement error: Algebra and statistics. Journal of Marketing Research, 18(3), 382-388.

Geroski, P., \& Murfin, A. (1990). Entry and industry evolution: the UK car industry 1958-83. Applied Economics, 23(4b), 799-809.

Golder, P. N., \& Tellis, G. J. (1993). Pioneer advantage: Marketing logic or marketing legend? Journal of Marketing Research, 30(2), 158-170.

Green, R. F., Lisboa, J., \& Yasin, M. M. (1993). Porter's (1980) generic strategies in Portugal. European Business Review, 93(2), 3-10.

Hair, J. F., Sarstedt, M., Pieper, T. M., \& Ringle, C. M. (2012). The use of partial least squares structural equation modelling in strategic management research: A review of past practices and recommendations for future applications. Long Range Planning, 45(5-6), 320-340.

Henseler, J., Dijkstra, T. K., Sarstedt, M., Ringle, C. M., Diamantopoulus, A., Straub, D. W., ... Calantone, R. J. (2014). Common beliefs and reality about PLS: comments on Rönkkö and Evermann (2013). Organizational Research Methods, 17(2), 182-209.

Henseler, J., Ringle, C. M., \& Sarstedt, M. (2014). A new criterion for assessing discriminant validity in variance-based structural equation modelling. Journal of the Academy of Marketing Science, 43(1), 115-135.

Hilman, H., \& Kaliappen, N. (2014). Do cost leadership strategy and process innovation influence the performance of Malaysia hotel industry? Asian Social Science, 10(10), 134-141.

Homburg, C., Krohmer, H., \& Workman, J. P., Jr. (2004). A strategy implementation perspective of market orientation. Journal of Business Research, 57(12), 1331-1340.

Kerin, R. A., Varadarajan, P. R., \& Peterson, R. A. (1992). First-mover advantage: A synthesis, conceptual framework, and research propositions. Journal of Marketing, 56(4), 33-52.

Kline, R. B. (2011). Principles and practice of structural equation modelling. New York: Guilford Press.

Klarner, P., Sarstedt, M., Hoeck, M., \& Ringle, C. M. (2013). Disentangling the effects of team competences, team adaptability, and client communication on the performance of management consulting teams. Long Range Planning, 46(3), 258-286. 
Lai, K. H. (2003). Market orientation in quality-oriented organizations and its impact on their performance. International Journal of Production Economics, 84(1), 17-34.

Lai, K. H., \& Cheng, T. C. E. (2005). Effects of quality management and marketing on organizational performance. Journal of Business Research, 58(4), 446-456.

Lai, K. H., Yeung, A. C. L., \& Cheng, T. C. E. (2012). Configuring quality management and marketing implementation and the performance implications for industrial marketers. Industrial Marketing Management, 41(8), 1284-1297.

Lee, S. G., Koo, C., \& Nam, K. (2010). Cumulative strategic capability and performance of early movers and followers in the cyber market. International Journal of Information Management, 30(3), 239-255.

Nunnally, J. C., \& Bernstein, I. (1994). Psychometric theory. New York: McGraw-Hill.

Otero, M. C., \& Varela, M. C. (2008). Influencia en las reacciones competitivas de las características de la acción y del liderazgo de la empresa. Investigaciones Europeas de Dirección y Economía de la Empresa, 14(1), 33-50.

Podsakoff, N. P., Shen, W., \& Podsakoff, P. M. (2006). The role of formative measurement models in strategic management research: Review, critique, and implications for future research. Research Methodology in Strategy and Management, 3, 197-252.

Porter, M. E. (1980). Estrategia competitiva. México: C.E.C.S.A.

Porter, M. E. (1985). Competitive advantage: Creating and sustaining superior performance. New York: Free Press.

Porter, M. E. (1991). Towards a dynamic theory of strategic. Strategic Management Journal, 12(S2), 95-117.

Preacher, K. J., \& Hayes, A. F. (2004). SPSS and SAS procedures for estimating indirect effects in simple mediation models. Behavior Research Methods, Instruments and Computers, 36(4), 717-731.

Preacher, K. J., \& Hayes, A. F. (2008). Asymptotic and resampling strategies for assessing and comparing indirect effects in simple and multiple mediator models. Behavior Research Methods, 40(3), 879-891.

Radas, S. (2005). Competitive rivalry and competitive strategy in relation to product and process innovation in leading Croatian firms. Economic and Business Review, 7(3), $195-216$.

Ringle, C. M., Wende, S., \& Becker, J. M. (2014). SmartPLS 3. Hamburg: SmartPLS. (Retrieved from http://www.smartpls.de).

Robinson, R. B., Jr. \& Pearce, J. A., II. (1988). Planned patterns of strategic behaviour and their relationship to business-unit performance. Strategic Management Journal, 9(1), 43-60.

Ruiz-Ortega, M.J., \& García-Villaverde, P. M. (2008). Capabilities and competitive tactics influences on performance: Implications of the moment of entry. Journal of Business Research, 61(4), 332-345.

Shamsie, J., Phelps, C., \& Kuperman, J. (2004). Better late than never: Study of late entrants in household electrical equipment. Strategic Management Journal, 25(1), 69-84.

Spanos, Y. E., Lioukas, S. (2001). An examination into the causal logic of rent generation: Contrasting Porter's competitive strategy framework and the resource-based perspective. Strategic Management Journal, 22(10), 907-934.

Zahra, S. A. (1993). Environment, corporate entrepreneurship, and financial performance: a taxonomic approach, Journal of Business Venturing, 8(4), 319-340.

Zahara, S. A., \& Covin, J. G. (1993). Business strategy, technology policy and firm performance. Strategic Management Journal, 14(6), 451-478. 